\title{
Sahîh-i Buhârî İcâzetli Kadın Muhaddis: Kerîme bnt. Abdülvehhâb
}

\author{
Arş. Gör. Abdurrahman KURT*
}

Atıf / @-- Kurt, A. (2018). Sahîh-i Buhârî İcâzetli Kadın Muhaddis: Kerîme bnt. Abdülvehhâb, Çukurova Üniversitesi Ilahiyat Fakültesi Dergisi, 18 (1), 453476.

Öz- Hicrî VI. (XII) asrın ikinci yarısı ile VII. (XIII) asrın birinci yarısında Şâm bölgesinde yaşayan Kerîme bnt. Abdülvehhâb'in içinde bulunduğu dönem ve muhit, sebep ve sonuçları itibariyle dünya ve İsâm tarihini yakından ilgilendiren Haçlı ve Moğol saldırıları gibi iki önemli hâdiseye tanık olmuştur. Bununla birlikte söz konusu hâdiselerin yol açtığı büyük kayıp ve yıkımlara rağmen bu dönemde ilmî faaliyetlerin tüm hızıyla devam ettiği ve câmi, medrese, dârülhadis, hânkâh gibi eğitim ve öğretim kurumlarının tesisinde büyük artışın meydana geldiği görülmektedir. Dımaşk şehrinde doğup büyüyen Kerîme, yetiştirdiği hadis âlimleriyle ön plana çıkmış saygın ve köklü bir aileye mensuptur. Bu durum onun henüz erken yaşlarda ilimle tanışmasına ortam hazırlamıştır. Gerek ilmiye sınıfından bir ailede yetişmiş olması gerekse ilim yolundaki şahsî gayret ve başarısı onu kısa sürede hadis ilminde şöhrete kavuşturmuştur. Bir döneme damgasını vurmuş ender şahsiyetlerden olan bu kadın muhaddis, yaşadığı uzun ömür sayesinde âlî isnâd sahibi olma pâyesi elde etmiştir. Bu sebeple çok sayıda hocayla görüşme ve onlardan hadis dinleme fırsatı bulmuş, nice talebenin yetişmesinde de aktif rol almıştır. Hadis ilminin önemli simaları, onun meclislerine katılabilmek için büyük bir şevkle evinin yolunu tutmuşlardır. Ömrünü hadis rivâyetine ve tedrisatına adayan Kerîme'nin en önemli hususiyeti ise Horasan bölgesinin meşhur hadis âlimlerinden Ebü'l-Vakt es-Siczî'den aldığı icâzetle İmâm Buhârînnin el-Câmi'u'sSahîh'ini ve ayrıca kendisinin rivâyet iznine sahip olduğu bir takım kitap ve cüzleri defalarca okutmuş olmasıdır. Kerîme'nin hayatı ve hadis ilmine katkısını konu edinen bu çalışma, onun özelinde tarihteki kadın muhaddislerin varlığını ve etkinliğini ortaya koymayı hedeflemiştir.

Anahtar sözcükler- Kerîme bnt. Abdülvehhâb, icâzet, rivâyet, kadın muhaddis, Sahîh-i Buhârî

Makalenin gelişi: 12.03.2018; Yayına kabul tarihi: 12.06.2018

* Kahramanmaraş Sütçü İmam Üniversitesi İlahiyat Fakültesi Hadis Anabilim Dalı, e-posta: abdurrahmankurt24@hotmail.com (ORCID: 0000-0002-0670-0038) 


\section{$\S \S \S$}

\section{Giriş}

İslâm tarihinde kadınlar, ilk asırlardan itibaren ilimle iç içe olmuşlardır. Biyografi eserlerinde kadınlar hakkındaki bilgilerin erkeklere nisbeten az olması onların, erkeklerin gölgesinde kaldıkları izlenimini verse de bu husus kadınların ihmal edildiğinin veya geri bırakıldığının göstergesi olamaz. Zira bu durum vâkıayla da örtüşmemektedir. Nitekim İslâm kültür tarihinde çok sayıda mümtaz kadın şahsiyetin yetiştiği ehlince malumdur. Genç kızların çeyizlerinde İmâm Şâfiî'nin (v. 204/820) önde gelen talebelerinden Ebû İbrahim İsmâîl el-Müzenî'nin (v. 264/878) fıkha dair el-Muhtasar isimli eserini bulundurmaya özen göstermiş olmaları, ${ }^{1}$ bu hususta söylenebilecek birçok şeyi özetler mahiyettedir.

Kerîme'nin içinde bulunduğu dönem, hadis ilminde temâyüz etmiş çok sayıda kadına ev sahipliği yapmıştır. Devrin önemli simaları bu kadın muhaddislerden ders alabilmek ve hadis rivâyetinde bulunabilmek için büyük bir gayret göstermişlerdir. Meselâ kadın hocalarından bahsettiği bir mu'cem kaleme alan Ebu'l-Kâsım İbn Asâkir'in (v. 571/1176), seksenden fazla kadın hocası olduğu zikredilmektedir. İbn Asâkir ayrıca Dımaşk'ın siyasî, sosyal ve kültürel tarihine ışık tuttuğu devasa eseri Târîhu Dımaşk'ında farklı sahalarda öne çıkmış iki yüzden fazla kadına yer vermiştir. ${ }^{3}$ Ebû Muhammed Abdülazîm b. Abdülkavî el-Münzirî (v. 656/1258) ise hadis ilminde şöhret bulmuş kadınlardan hadis dinlemek veya icâzet alabilmek maksadıyla şehir şehir dolaşmış muhaddislerdendir. Kadın hocalarından övgüyle bahseden Münzirî, onlarla görüşüp hadis ve icâzet aldığı tarihleri dahi titizlikle kaydetmiştir. ${ }^{4}$ İbnü’lBuhârî diye tanınmış muhaddislerden Ali b. Ahmed el-Makdisî (v. 690/1291) de kendilerinden hadis dinlediği bayan hocalarını ve rivâyetlerini Meşyaha'sında zikretmiştir. ${ }^{5}$

1 Zehebî, Siyeru allâmi'n-nübelâ (thk. Şuayb el-Arnaût v. dğr.), Müessesetü'r-risâle, Beyrut, 1405/1985, XII, 493.

2 Zehebî, Siyer, XX, 556.

3 Bk. İbn Asâkir, Târîhu medîneti Dımaşk (thk. Muhibbüddîn Ebû Saîd Ömer), Dârü'l-fikr, Beyrut, 1415/1995, LXIX. ve LXX. ciltler.

4 Münzirî'nin kadın hocaları hakkında yapılmış bir çalışma için bk. Kurt, Rabia, "Münzirî̀nin (v. 656/1258) Hadis Aldığı Kadın Hocaları Hakkında Bir Değerlendirme (et-Tekmile Özelinde)", Kahramanmaraş Sütçü İmam Üniversitesi İlahiyat Fakültesi Dergisi, 15/29, (2017), s. 193225.

5 İbnü'l-Buhârî, Meşyahatü İbni'l-Buhârî (thk. Avaz Itkî), Dârü âlimi'l-fevâid, Mekke, 1419/1998, III, 1813-1925. 
İmkânları ölçüsünde her türlü fedakârlığa katlanarak ilim yolculuğuna dahi çıkan kadın muhaddisler, gittikleri yerlerde rivâyetine sahip oldukları kitap ve cüzleri okutarak hadis ilminde aktif rol oynamışlardır. Bu isimlerden Sittü'lKetebe lakaplı Nimet bnt. Ali (v. 604/1207) Dımaşk, Bağdât ve Hicâz gibi şehirlerde hadis rivâyet etmiştir. ${ }^{6}$ Fatıma bnt. İbrahim el-Ba'lebekkîyye (v. 711/1311) de hac görevini yerine getirmek maksadıyla gittiği Hicâz'da hadis okutmuştur. O tarihlerde Hicâz'da bulunan Endülüslü muhaddis ve seyyah İbn Rüşeyd (v. 721/1321), Fatıma'nın ravza-i mutahhara'da revaklardan birine yaslanmış bir vaziyette hadis okuttuğundan övgüyle bahsetmiştir. ${ }^{7}$ Bütün bunlar, hicrî 6 ve 7. asırlarda kadın muhaddislerin hadis ilmine önemli katkılar sunduğunu ortaya koymaktadır.

\section{Doğumu ve Nesebi}

Tam adı Kerîme bnt. Abdülvehhâb b. Ali b. Hadır b. Abdullah b. Ali b. Ahmed b. Ali b. Muhammed b. Ali b. Abdullah b. Abdülazîz b. Abdülvehhâb b. Yahyâ b. Abbâd b. Abdullah b. Zübeyr b. Avvâm el-Kureşiyye el-Esediyye ezZübeyriyye ed-Dımaşkiyye'dir. ${ }^{8}$ Ümmü Fadl künyesini taşıyan Kerîme, soy itibariyle Hz. Peygambere ilk iman edenler arasında yer almış Kureyş kabilesinin Esed koluna mensup meşhur sahâbî Zübeyr b. el-Avvâm'a (v. 36/656) dayandığından el-Kureşiyye, el-Esediyye, ez-Zübeyriyye; Dımaşk'ta doğup büyümesi ve orada ikamet etmesinden dolayı da ed-Dımaşkiyye nisbeleriyle anılmıştır.

Akranı ve aynı zamanda talebesi Münzirî, et-Tekmile li Vefeyâti'nnakale isimli eserinde hocasının tahminen 545/1150 veya 546/1151 yılında doğduğunu kaydetmiştir. ${ }^{9}$ Hayatına yer veren sonraki kaynaklar da bu hususta Münzirî̀yi takip ederek aynı tarihleri zikretmişlerdir. Ancak Zehebî (v. 748/1348), diğer kaynaklar gibi Târîhu'l-Islâm'da 545/1150 veya 546/1151 yılını zikretmesine rağmen Siyer'inde Kerîme'nin 546/1151'de doğduğunu belirtmiştir. ${ }^{10}$

6 Münzirî, et-Tekmile li-Vefeyâti'n-nakale (thk. Beşşâr Avvâd), Müessesetü'r-risâle, Beyrut, 1405/1984, II, 130; Zehebî, Târîhu'l-İslâm ve vefeyâtü'l-meşâhir ve'l-a'lâm (thk. Ömer Abdüsselâm Tedmürî), Dârü'l-kitâbi'l-Arabî, Beyrut, 1418/1997, XLIII, 146.

7 İbn Rüşeyd, Mil'ü'l-'aybe bimâ cümi‘a bi-tûli'l-ğaybe fi'l-vicheti'l-vecîhe ile'l-Harameyn Mekke ve Taybe, (thk. Muhammed el-Habîb), Tunus, 1402/1982, V, 21. Ayrıca bk. Yılmaz, Muhammet, Kadın Hadisçiler, Araştırma Yayınları, Ankara, 2008, s. 63.

8 Hüseynî, Sılatü't-Tekmile li-Vefeyâti'n-nakale (thk. Beşşâr Avvâd), Dârü'l-garbi'l-İslâmî, Beyrut, 1428/2007, I, 67-68.

9 Münzirî, et-Tekmile, III, 624.

10 İbnü's-Sâbûnî, Tekmiletü İkmâli'l-Ikmâl fi'l-ensâb ve'l-esmâ ve'l-elkâb (thk. Mustafa Cevâd), Matbûâtü'l-mecmai'I-ilmiyyi'l-Irâkî, Irak, 1377/1957, s. 284; Hüseynî, Sılatü't-Tekmile, I, 68; 


\section{Ailesi ve Yetiştiği İlmî Muhit}

Kerîme'nin mensubu olduğu aile, Dımaşk'ın köklü ve önde gelen ailelerindendir. Benû Habakbak ${ }^{11}$ diye de tanınan bu aile hadis ilmi başta olmak üzere muhtelif disiplinlerde yetiştirmiş olduğu ilim adamları ile devletin önemli kademelerinde görev almış fertleriyle meşhur olmuştur. Aile efradının neredeyse tamamının hadis ilmiyle meşgul olduğunu söylemek mümkündür. Nitekim aile fertlerinden bir kısmını yakından tanıyan isimlerden Münzirî ve İbnü'sSâbûnî'nin (v. 680/1282) yanı sıra pek çok âlim, söz konusu aileden bahsederken kullanmış oldukları beytü'l-ilm ve'l-hadîs, beytün meşhûrün bi'l-adâle, ma'rûfün bi'r-rivâye ${ }^{12}$ gibi ifadelerle ailenin hadis ilmindeki tanınmışlığına dikkat çekmişlerdir.

Ebu'l-Hasan Ali b. Müsellem es-Sülemî, Ebu'l-Feth Nasrullah b. Muhammed el-Mıssîsî, Ebü'd-Dürr Yâkût b. Abdullah, Ebû Ya'lâ Hamza İbnü'lHubûbî ve daha başka âlimlerden hadis dinleyen Kerîme'nin babası Ebû Muhammed Abdülvehhâb b. Ali (v. 590/1194), ailenin ileri gelenlerinden olup aile fertlerinin eğitimiyle yakından ilgilenmiştir. Münzirî'nin "hocamız Kerîme'nin babası" diye tarif ettiği Abdülvehhâb'ın ilminden, kardeşi Ebu'l-Mehâsin Ömer b. Ali (v. 575/1179), çocukları Kerîme ve Ali b. Abdülvehhâb'ın (v. 618/1221) yanı sıra Ebu'l-Mevâhib İbn Sasrâ (v. 586/1190) ve Yûsuf b. Halîl b. Karâcâ (v. 648/1250) gibi muhaddisler de faydalanmıştır. ${ }^{13}$

Kerîme'nin amcası Ebu'l-Mehâsin Ömer ise, Bağdât'a yerleşen devrin hadis hâfızlarındandır. Küçük yaşlardan itibaren kendini hadis ilmine veren Ebu'l-Mehâsin, Dımaşk, Haleb, Harran, Musul, Bağdât, Kûfe ve Hicâz gibi şehirlere ilim seyahatlerinde bulunmuştur. Bu bağlamda pek çok âlimden ders alma fırsatı yakalamıştır. Bununla birlikte dönemin fakih ve muhaddis mutasavvıflarından Ebu'n-Necîb es-Sühreverdî’ye (v. 563/1168) mülazemet ederek

Zehebî, Târîhu'l-Islâm, XLVII, 93; Siyer, XXIII, 93; Safedî el-Vâfî bi'l-vefeyât, (thk. Ahmed elArnaût-Türkî Mustafa), Dâru ihyâi't-türâsi'l-Arabî, Beyrut, 1420/2000, XXIV; 254; Fâsî, Zeylü'tTakyîd li ma'rifeti ruvâti's-sünen ve'l-mesânîd (thk. Muhammed Sâlih), Merkezü ihyâi't-türâsi'lİslâmî, Mekke, 1418/1997, III, 449.

11 Zehebî, Siyer, XXIII, 92; Fâsî, Zeylü't-Takyîd, III, 448; İbn Hacer, Nüzhetü'l-elbâb fi'l-elkâb, (thk. Abdülazîz b. Muhammed), Mektebetü'r-Rüşd, Riyâd, 1409/1989, I, 195.

12 Münzirî, et-Tekmile, II, 477; III, 327, 624; İbnü's-Sâbûnî, Tekmiletü İkmâli'-ikmâl, s. 283; Hüseynî, Sılatü't-Tekmile, I, 68, 196; Muhammed Mutî́ el-Hâfı, Mevsû'atü'l-büyûtâti'l-ilmiyye bi-Dımaşk, Dârü'l-fikr, Dımaşk, 1435/2014, III, 109.

13 Münzirî, et-Tekmile, I, 202; Zehebî, Târîhu'l-İslâm, XLI, 382; Siyer, XXI, 230-23; el-iber fî haberi men gaber (thk. M. Saîd Zağlûl), Dârü'l-kütübi'l-ilmiyye, Beyrut, 1405/1985, III, 101; İbnü'l-İmâd, Şezerâtü'z-zeheb fî ahbâri men zeheb (thk. Abdülkâdir el-Arnaût-Mahmûd elArnaût), Beyrut, 1406/1986, VI, 494. 
ondan istifade etmiştir. ${ }^{14}$ Müteahhir ulema arasında Ebu'l-Mehâsin'den daha çok hadis tahsil eden kimseye rastlanmadığını ancak onun genç yaşlarda vefat etmiş olması sebebiyle çokça hadis rivâyet edemediğini belirten İbnü'nNeccâr el-Bağdâdî (v. 643/1245), Ebu'l-Mehâsin'in 800 veya daha fazla hocayı ihtiva eden bir Mu'cem kaleme aldığından bahsetmektedir. ${ }^{15}$ Günümüze ulaşmadığı anlaşılan bu eser, İbn Nukta'nın (v. 629/1231) et-Takyîd isimli eserinin kaynakları arasında yer almakta ve İbn Nukta, buradaki rivâyetleri vicâde yoluyla nakletmektedir. ${ }^{16}$ İbn Nukta'nın ondan aktardığı bir rivâyete göre Ebu'l-Mehâsin 560/1165 yılında Ebu Zür'a el-Makdisî'den (v. 566/1171) Sünen-i İbn Mâce'yi semâ etmiştir. ${ }^{17}$ Ebu'l-Mehâsin, dönemin Bağdât kâdılkudât'ı Ebû Tâlib Ravh b. Ahmed (v. 570/1175) tarafından kadılık vazifesine atanmış, ayrıca elçi sıfatıyla Şam emiri Nûreddîn Zengî'ye (v. 569/1174) ziyâretler gerçekleştirmiştir. Defalarca hacca giden Ebu'l-Mehâsin'in, orada hadis rivâyetinde bulunduğunda yaşının henüz otuza varmadığı zikredilmektedir. ${ }^{18}$ Kendisine bütün rivâyetlerinin icâzetini verdiğini dile getiren İbnü'dDübeysî (v. 637/1239), âlimlerin güvenilir kabul ettikleri Ebu'l-Mehâsin'den övgüyle bahsettiklerini söylemiştir. ${ }^{19}$

Kerîme'nin amcasının oğlu Abdullah b. Ömer de (v. 616/1219) ailenin bir diğer hadis âlimi olup babasının riyasetinde pek çok hocadan hadis dinlemiştir. ${ }^{20}$ Bağdât'ta ikamet eden ve ticaretle meşgul olduğu için sıklıkla Şam bölgesine gidip gelen Abdullah, yolculukları esnasında güzergâhı üzerindeki yerlerde hadis rivâyetinde bulunmuştur. Nitekim rivâyet hakkına sahip olduğu Ebû Bekr Ahmed b. İbrahim el-İsmâîli'nin (v. 371/982) el-Müstahrec'ini Dımaşk'ta rivâyet etmiştir. ${ }^{21}$ Meşyaha'sında Abdullah'a yer veren devrin bir asır

14 İbnü'd-Dübeysî, Zeylü Târîhi Bağdât, Zeylü Târîhi Bağdâd (thk. Beşşâr Avvâd), Dârü'l-garbi'lİslâmî, Beyrut, 1427/2006, IV, 329-330; Zehebî, Târîhu'l-İslâm, XL, 175-176; Siyer, XXI, 105106; Tezkiretü'l-huffâz (thk. Zekeriyyâ Umeyrât), Dârü'l-kütübi'l-ilmiyye, Beyrut, 1419/1998, IV, 106-107.

15 İbnü's-Sâbûnî, Tekmiletü İkmâli'-lkmâl, (nâşirin notu) s. 283-284; Muhammed b. Azzûz, Buyûtâtü'l-hadîs bi-Dımaşk, Dârü'l-fikr, Dımaşk 1425/2004, s. 75.

16 İbn Nukta, et-Takyîd li ma'rifeti ruvâti's-sünen ve'l-mesânîd (Şerîf b. Sâlih), Dârü'n-nevâdir, Beyrut, 1435/2014, I, 84-86.

17 İbn Nukta, et-Takyîd, II, 564.

18 İbnü'd-Dübeysî, Zeylü Târîhi Bağdâd, IV, 330-331.

19 İbnü'd-Dübeysî, Zeylü Târîhi Bağdâd, IV, 331.

20 İbnü'd-Dübeysî, Zeylü Târîhi Bağdâd, III, 470-471; Münzirî, et-Tekmile, II, 477; Zehebî, Târîhu'l-İslâm, XLIV, 296.

21 İbn Nukta, et-Takyîd, II, 606. 
yaşamış meşhur muhaddislerinden İbnü'l-Buhârî, 612/1215 yılında Emevî Camii'nde ondan hadis dinlemiştir. ${ }^{22}$

Ailenin hadis ilmiyle şöhret bulmuş önemli isimleri arasında Kerîme'nin kardeşleri Ebu'I-Hasan Ali ile Ümmü Hamza Safiyye (v. 646/1248) de bulunmaktadır. Münzirî’ye defalarca icâzet yazıp gönderen Ali'den, Yusûf b. Halîl b. Karâcâ, Şihâbüddîn el-Kûsî (v. 653/1255) ve Ziyâüddîn el-Makdisî (v. 643/1245) gibi hadis hafızları hadis dinlemiştir. ${ }^{23}$ Safiyye ise yaklaşık 90 yıllık ömrüyle ablası Kerîme gibi bir devre damga vurmuş kadın muhaddislerin önde gelenlerindendir. Hama kadısı Muhyiddîn Hamza el-Behrânîyle evli olduğundan Hama'ya yerleşen bu kadın muhaddisin yetişmesinde amcası Ebu'l-Mehâsin Ömer'in büyük katkısı olmuştur. Amcası, yeğeni için İsfahân ve Bağdât hadis âlimlerinden icâzet almıştır. Ebu't-Tâhir İsmail İbnü'l-Enmâtî (v. 619/1222), Ebu'l-Feth İbnü'l-Hâcib (v. 630/1233), Abdülmü'min ed-Dimyâtî (v. 705/1306) ve Ebû Bekr Ahmed ed-Deştî (v. 713/1313) gibi önemli isimler ondan hadis dinlemiştir. Dimyâtî'nin, 646/1249 yılında vefat eden Safiyye'nin cenazesine katılmış olması, ${ }^{24}$ hocasının onun katında ne kadar değerli olduğunu göstermektedir.

Kerîme bnt. Abdülvehhâb, İslâm ve dünya tarihini yakından ilgilendiren bir zaman ve zeminde yaşamıştır. Zira o, Zengîler (521/630-1127/1233) ve Eyyûbîler (567/866-1171/1462) gibi siyasî, sosyal, iktisadî ve kültürel alanlarda tarihe geçmiş iki önemli devletin hâkimiyetine şahit olmuştur. Söz konusu devletler, bu devirde İslâm dünyası için önemli bir tehdit unsuru haline gelen Haçlılar'la çetin bir mücadele vermiş ve büyük bir oranda da başarılı olmuşlardır. Nitekim bu mücadele Salâhüddîn Eyyûbî (v. 589/1193) zamanında Kudüs'ün fethiyle (583/1187) taçlandırıımışıı. Bununla birlikte ŞiîFâtımîlere karşı gösterilen mücadeleyle Bâtınî tehlikesi ortadan kaldııımaya çalışımış ve İslâm siyasî birliğinin tesisinde önemli adımlar atılmıştır. ${ }^{25}$

Kerîme'nin yaşadığı Şâm bölgesinin en önemli şehri olan Dımaşk, gerek Zengîler gerekse Eyyûbîler hâkimiyetinde İslâm coğrafyasının gözde ve merkezî yerleşim birimlerinden biri haline gelmiştir. Burası, özellikle kültürel anlamda yüksek bir seviye yakalamıştır. Kur'ân, Hadis ve Fıkıh gibi ilimlerin

22 İbnü'l-Buhârî, Meşyaha, II, 1249-1259.

23 Münzirî, et-Tekmile, III, 37; Zehebî, Târîhu'IIIslâm, XLIV, 412.

24 Hüseynî, Sılatü't-Tekmile, I, 195-196; Zehebî, Târîhu'l-Islâm, XLVII, 310-311; Siyer, XXIII, 270.

25 Zengîler ve Eyyûbîler hakkında geniş bilgi için bk. Şeşen, Ramazan, Eyyûbîler, İsam Yay., İstanbul, 2012; es-Sallâbî, Ali Muhammed, ed-Devletü'z-Zengiyye, Dârü'l-ma'rife, Beyrut, 2007. 
merkezi olarak görülen Dımaşk, özellikle Nûreddîn Zengî, muhaddis İbn Asâkir ve Kudüs'ten hicret ederek burayı vatan edinmiş Makdisî ailesi zamanında ilim alanında büyük bir ilerleme kaydetmiştir. ${ }^{26}$ Zira Nûreddîn Zengî ve Salâhüddîn Eyyûbî başta olmak üzere, aynı zamanda birer ilim adamı vasfını taşıyan devlet yöneticileri Dımaşk'ın ilim ve kültür şehri olması için büyük bir özveriyle çalışmışlardır. Bu çerçevede medrese, dârülhadis, câmi, hânkâh gibi çok sayıda eğitim kurumu inşa edilmiştir. ${ }^{27}$ İslâm tarihinde resmî olarak ilk dârülhadis bu devirde Nûreddîn Zengî tarafından tesis edilmiş, ${ }^{28}$ Eyyûbîlerle birlikte ise dârülhadislerin sayısında büyük bir artış sağlanmıştır.

İlim alanında meydana gelen faaliyet ve gelişmeler neticesinde Dımaşk büyük bir cazibe merkezi haline gelmiştir. Bu durum pek çok ilim adamının dikkatini çekmiş ve akın akın şehre gelmelerini sağlamıştır. Nitekim şehir Mısır, Hicâz, Horâsân, Bağdât gibi Doğu İslâm coğrafyasında yer alan şehirlerdeki âlimler ile Endülüs ve Mağrib bölgesinden gelen âlimlerle dolup taşmıştır. ${ }^{29}$ Önemli bir kısmı ilim ortamını beğendiği bu şehirde ömür boyu ikâmet etmeyi tercih etmiştir. Yerli ve yabancı âlimlerin bu buluşması İslâm dünyasında kültürel ve ilmî birikimin yayılmasında oldukça önemli bir misyon icra etmiştir.

Hem yöneticiler hem de halk, hadis ilmine ve muhaddislere büyük bir rağbet göstermiştir. ${ }^{30} \mathrm{Bu}$ saygınlık çok sayıda hadis âliminin yetişmesine imkân sağlamıştır. Şam diyarının tartışmasız muhaddis ve tarihçilerinden Ebu'l-Kâsım İbn Asâkir, Ebû Muhammed İbn Asâkir (v. 600/1203) ile Ebû Mansûr İbn Asâkir (v. 620/1223) gibi Benû Asâkir ailesinin önemli fertleri, Cemmâîîi diye meşhur Abdülğanî b. Abdülvâhid el-Makdisî (v. 600/1203) ile Ziyâüddîn el-Makdisî gibi Benû Kudâme ailesinin müstesna isimleri, yazdığı

26 Zehebî, el-Emsâr zevâtü'l-âsâr (thk. Mahmûd el-Arnaût), Dârü İbn Kesîr, Dımaşk, 1405/1985, s. 26.

27 Bu devirde kurulmuş eğitim müesseseleri hakkında bk. Nuaymî, ed-Dâris fî târîhi'l-medâris, III, Beyrut, 1410/1990. Ayrıca bu dönemin medreselerine dair yapılmış iki çalışma için bk. Şümeysânî, Hasan, Medârisu Dımaşk fi'l-asri'l-Eyyûbî; Beyrut, 1403/1983; Yılmaz, Harun, Zengî ve Eyyûbî Dımaşk'ında Ulema ve Medrese, İstanbul, 2017.

28 İbnü'l-Esîr, et-Târîhu'l-bâhir fi'd-devleti'l-Atâbekiyye (thk. Abdülkâdir Ahmed), Dârü'l-kütübi'lhadîse, Kahire, 1383/1963, s. 172; Makrizî, el-Mevấiz ve'l-i'tibâr bi-zikri'l-hıtat ve'l-âsâr, Mektebetü medbûlâ, Kahire, 1419/1998, III, 467-468.

29 Dımaşk'ın ilim ve kültür hayatına katkıda bulunmuş Mağribli hadis âlimleri hakkında bir çalışma için bk. Muhammed b. Azzûz, el-Muhaddisûne'l-Meğâribe fî Dımaşk, Dârü İbn Hazm, Beyrut, 1431/2010.

30 Meselâ hadis ilmi ve âlimlerine duyduğu ilgiyle tanınan Eyyûbî meliklerinden Eşref Mûsâ (v. 635/1237), Eşrefiyye dârülhadisini kurarak yönetimine meşhur muhaddis İbnu's-Salâh'ı atamıştır. Bk. İbn Hallikân, Vefeyâtü'l-a'yân ve enbâü ebnâi'z-zamân (thk. İhsân Abbâs), Dârü sâdır, Beyrut, 1398/1978, V, 334. 
Ulûmu'l-hadis'le hadis usûlüne yeni bir soluk katan İbnü's-Salâh (v. 643/1245) ve hadis ilminin muhtelif alanlarında eserler kaleme almış Nevevî (v. 676/1277) ve daha pek çok isim bu devirde yetişmiş önemli hadis âlimlerindendir.

Kerîme, bahsedildiği üzere ilim seviyesinin ileri düzeyde olduğu bir ortamda doğup büyümüştür. Ailesinin ilmiye sınıfına sahip olması neticesinde kendisine verilen eğitimle birlikte şahsî cehd ve gayretiyle elde ettiği imkân ve fırsatları değerlendirmiş ve böylece hadis ilminde haklı bir şöhrete ulaşmayı başarmışıır.

\section{Hadis İlmindeki Yeri}

\section{a. Hocaları}

İslâm eğitim tarihinde talebenin eğitim ve öğretiminde ya da ilmî formasyonu elde etmesinde hoca en önemli etken olarak görülmüştür. Bu sebeple öğrenilecek bilginin mutlaka bir hoca nezaretinde gerçekleşmesine önem verilmiştir. Hoca aracılığıyla öğrenilmeden elde edilen bilgiye pek itibar edilmemiştir. Hatta okunacak bir kitabın dahi hoca eşliğinde mütalaa edilmesi tavsiye edilmiştir. Özellikle şifahî kültürün yaygın olduğu dönemler göz önünde bulundurulduğunda hoca faktörünün ne kadar önemli olduğu anlaşılmaktadır. Bu sebeple kitabı hoca yerine koymak musibetin en büyügü olarak görülmüştür. Nitekim Imâm Şafiî̀nin, "Her kim fıkhı kitaplardan öğrenirse hükümleri zâyi eder" dediği rivâyet edilmektedir. ${ }^{31}$

Kerîme'nin içinde bulunduğu dönemde de bizzat hocalarla görüşüp onlardan ilim almaya özen gösterilmiş ve herhangi bir hadis metnini veya kitabını, rivâyet hakkına sahip âlimin bizzat kendisinden okumak ilim ehlinin önem verdiği ve üzerinde durduğu hususların başında yer almıştır. Çocukların erken yaşlarda ilim meclislerine götürülmesinin yaygın bir gelenek haline geldiği bu devirde âlimler, kız çocuklarını da gerek şehirdeki gerekse hadis rivâyeti için dışardan gelen âli isnâd sahibi hocalardan istifade etmeleri için kendileriyle hadis meclislerine özellikle getirmişlerdir. Meselâ Hanbelî hadis âlimi Muhammed b. Halef b. Râcih (v. 618/1221) hadis rivâyeti için Dımaşk'a gelen devrin meşhur müsnidlerinden Ömer b. Taberzed el-Bağdâdînnin ( $v$. 607/1210) meclislerine kızı Hatice'yi de götürmüştür. Hatice, İbn Taber-

31 Bk. İbn Cemâa, Tezkiretü's-sâmi ve'l-mütekellim fî edebi'l-âlim ve'l-müteallim (thk. Muhammed Mehdî), Dârü'l-beşâiri'l-İslâmiyye, Beyrut, 1433/2016, s. 97. 
zed'den Vâkidî'nin (v. 207/823) Meğâzîsini dinlerken henüz 4 yaşında bir çocuk olarak semâ kayıtlarına geçmiştir. ${ }^{32}$

Birçok ilim ehli gibi Kerîme de ilk eğitimini babasından almış ve onun gözetiminde yetişmiştir. Abdülvehhâb katıldığı hadis meclislerinde kızı Kerîme'yi de yanında bulundurarak devrin meşayıhından hadis dinlemesini sağlamıştır. Henüz çocuk sayılabilecek yaşta olan Kerîme bu vesileyle İbn Asâkir'in de kendilerinden faydalandığı İbnü'l-Hubûbî diye marûf Ebû Ya'lâ Hamza b. Ali (v. 555/1160), Ebû Muhammed Abdurrahman b. Ebu'l-Hasan ed-Dârânî (v. 558/1163), Ebu'n-Nedâ Hassân b. Temîm ez-Zeyyât (v. 560/1165), Ebu'l-Hasan Ali b. Ahmed el-Harestânî (v. 561/1166), Ebu'l-Hasan Ali b. Mehdî ed-Dımaşkî (v. 562/1167) ${ }^{33}$ gibi pek çok hocadan hadis dinlemiştir. Nitekim 558/1163 yılına ait bir semâ kaydına göre Abdülvehhâb'ın kendi evinde Müsnedü Abdullah b. Ömer'in okunması için bir meclis tertip ettiği, dersin hocası Abdurrahman b. Ebu'l-Hasan ed-Dârânî önderliğinde gerçekleştirilen bu mecliste Kerîme ile birlikte kardeşleri Ümmü'l-Hayr Halîme, Ebu'lHasan Ali ve anneleri Sittü'l-Meâli bnt. Muhammed'in de iştirak ettiği görülmektedir. ${ }^{34}$ Küçük yaşlarda hocaların huzuruna getirilen kız çocukları uzun bir ömür yaşadıklarında ilerleyen zamanda kendisinden istifade ettiği hocanın hayatta kalan tek öğrencisi olma vasfını kazandığından Kerîme de sözü edilen hocaların en son ve seçkin talebesi olma vasfını haiz olmuştur.

Hadis ilminde semâ ve kıraat gibi bizzat hocayla mülaki olma dışında icâzet usulüyle de hocadan yararlanmanın genel kabul görmüş olması ${ }^{35}$ özellikle kadınlara büyük bir kolaylık sağlamıştır. Bu durum çok sayıda hocaya sahip olmayı beraberinde getirmiştir. Bu bağlamda Kerîme sadece Dımaşk'taki hocalarla yetinmemiş, İsfahân ve Bağdât meşayıhından çok sayıda muhaddisten de icâzet almıştır. Bu isimlerden bazıları şunlardır: Ebü'l-Vakt Abdülevvel es-Siczî (v. 553/1158), Ebu'l-Hayr Muhammed b. Ahmed elBağbân (v. 559/1164), Ebû Muhammed Abdülkâdir el-Cîlî (el-Geylânî) (v. 561/1166), Ebû Abdullah Hasan b. Abbâs er-Rüstümî (v. 561/1166), Ebû Tâlib

32 Bk. Muhammed b. Azzûz, Cühûdü'I-mer'ati'd-Dımaşkiyye fî rivâyeti'l-hadîsi'ş-şerîf, Dârü'l-fikr, Dımaşk, 1425/2004, s. 31-32.

33 Münzirî, et-Tekmile, III, 623; İbnü’s-Sâbûnî, Tekmiletü İkmâli'l-ikmâl, s. 282; Hüseynî Sılatü'tTekmile, I, 68; Zehebî, Siyer, XXIII, 93.

34 Semâ kaydı için bk. Muhammed Mutî' el-Hâfız, Mevsû'atü'l-büyûtâti'l-ilmiyye bi-Dımaşk, III, 118-119.

35 İcâzet ve çeşitleri hakkında bk. Kâdî İyâz, el-İlmâ' ilâ ma'rifeti usûli'r-rivâye ve takyîdi's-semâ' (thk. Ahmed Ferîd), Dârü'l-kütübi'l-ilmiyye, Beyrut, 1430/2009, s. 38-48; İbnü's-Salâh, Ulûmu'l-hadîs (thk. Nûreddîn Itr), Dârü'l-fikr, Dımaşk, 1427/2006, s. 151-165; Suyûtî, Tedrîbu'r-râvî fî şerhi Takrîbi'n-Nevevî (thk. Bedî‘ es-Seyyid el-Lehhâm), Dârü'l-kelimi't-tayyib, Dımaşk, 1426/2005, I, 436-454. 
Mübârek b. Ali el-Bağdâdî (v. 562/1167), Ebu'l-Meâlî Muhammed b. Muhammed İbnü'l-Lehhâs (v. 562/1167), Ebu'l-Ferec Mesûd b. Hasan es-Sakafî (v. 562/1167), Ebû Ahmed Ma'mer b. Abdülvâhid el-Kureşî (v. 564/1169), Ebû Muhammed Abdülhâkim b. Zafer es-Sakafî (v. 564/1169), Ebu'l-Feth Muhammed b. Abdülbâki İbnü'l-Battî el-Bağdâdî (v. 564/1169), Ebu'l-Kâsım Mahmûd b. Abdülkerîm el-ísfahânî (v. 565/1170), Ebû Bekr Muhammed b. Abdülbâkî İbnü'l-Battî el-Bağdâdî (v. 565/1170), Ebû Mesûd Abdurrahîm b. Ebu'l-Vefâ el-Issfahânî (v. 566/117), Ebu'l-Kâsım Yahyâ b. Sâbit b. Bündâr elBağdâdî (v. 566/1171), Ebu'l-Mutahhar Kâsım b. Fadl es-Saydalânî (v. 567/1172), Ebû Ca'fer Muhammed b. Hasan es-Saydalânî (v. 568/1173), Ebû Mûsâ Muhammed b. Ömer el-Medînî (v. 581/1185), Ebu'l-Ferec Sâbit b. Muhammed el-İsfahânî (v. 595/1199), Ebu'l-Kâsım Recâ b. Hâmid el-İsfahânî (v. 560'lı yıllar), Ebû Saîd Abdülcebbâr b. Muhammed es-Sâlihânî (v. ?), Ebu'lFadl Mahmûd b. Muhammed eş-Şehhâm (v. ?), Ebû Mansûr Mesûd b. Abdülvâhid eş-Şeybânî (v. ?). ${ }^{36}$

Kerîme'nin hocaları elbette zikredilen isimlerle sınırlı değildir. Zira uzun bir ömür yaşadığından onun pek çok hocayla görüştüğünü ya da icâzet aldığını söylemek mümkündür. Zehebî'nin verdiği bilgiye göre Kerîme'nin talebelerinden Zekiyyüddîn el-Birzâlî (v. 636/1239), hocası adına sekiz ciltlik bir Meşyaha tahric etmiştir. ${ }^{37}$ Zehebî̀nin de semâ ettiği ancak günümüze ulaşmayan bu Meşyaha Kerîme'nin hocalarının sayısının bir hayli kabarık olduğunu göstermektedir.

\section{b. Talebeleri}

Hayatını hadis rivâyet ve eğitimine adayan Kerîme, yetiştirmiş olduğu sayısız talebeyle de hadis ilmine mühim bir katkı sağlamıştır. İçlerinde Ziyâüddîn el-Makdisî, Zekiyyüddîn el-Birzâlî, Şemsüddîn Yûsuf b. Halîl b. Karâcâ, Zekiyyüddîn Abdülazîm el-Münzirî, Ebû Şâme el-Makdisî (v. 665/1267) ve Cemâlüddîn İbnü's-Sâbûnî gibi büyük hadis hâfızlarının ve imamlarının bulunduğu pek çok muhaddisin Kerîme'den ders almak için çaba sarf etmiş olmaları onun hadis ilminin önemli temsilcilerinden olduğunu açıkça ortaya koymaktadır. Söz konusu talebeleri aracılığıyla bu kadın muhaddisin ilmî müktesebâtı nesilden nesile aktarılmıştır. Zikredilen isimler dışında ondan hadis dinlemiş bazı âlimler ise şunlardır: Ebu'l-Muzaffer Yûsuf b. Hasan en-

36 Münzirî, et-Tekmile, III, 623-624; Hüseynî, Sılatü't-Tekmile, I, 68; Muhammed Mutî‘ el-Hâfız, A'lâmü'n-nisâi'd-Dımaşkiyyât, Dârü'l-mektebî, Dımaşk, 1434/2013, s. 118-120; Muhammed b. Azzûz, Cühûdü'l-mer'a, s. 194-195.

37 Zehebî, Siyer, XXIII, 93. 
Nâblusî (v. 671/1273), Ebû Abdullah Muhammed b. Abdülmünim el-Harrânî (v. 671/1273), Ebu'l-Kâsım Ali b. Balabân el-Makdisî (v. 684/1284), Ebu'lBerekât Muhammed b. Ömer ed-Dîneverî (v. 685/1285), Ebu'l-Abbâs Ahmed b. Muhammed ez-Zâhirî (v. 696/1296), Ebû Abdullah Muhammed b. Hasan elUrmevî (v. 700/1300), Ebû Muhammed Abdülmünim b. Abdüllatîf (v. 700/1300), Ahmed b. Abdurrahman b. Mü'min es-Sâlihî (v. 701/1301), Ebû Ömer Dâvûd b. Hamza el-Makdisî (v. 701/1301), Ebû Hafs Ömer b. Muhammed el-Fârisî (v. 702/1302), Ebû Ali Hasan b. Ali İbnü'l-Hallâl (v. 702/1302), Ebû Muhammed Abdullah b. Mervân el-Fârikî (v. 703/1303), Ebu'l-Hasan Ali b. Ahmed el-Hâşimî (v. 704/1305), Ebû Abdullah Muhammed b. Yûsuf elErbilî (v. 705/1306), Fatıma bnt. Süleymân el-Ensârî (v. 708/1308) Sittü'l-Fahr bnt. Abdurrahman b. Ahmed eş-Şîrâzî (v. 709/1309), Sittü'l-Kudât bnt. Yahyâ b. Ahmed eş-Şîâizî (v. 712/1312), Ebû İshâk İbrahim b. Abdurrahman eşŞîrâzî (v. 714/1314), Ebu'l-Fadl Süleymân b. Hamza el-Makdisî (v. 715/1315), Ebû Muhammed İsâ b. Abdurrahman es-Sâlihî (v. 719/1320), Ebu'l-Mehâsin İbnü'l-Hırakî (v. ?), Hatîce bnt. Temîme (v. ?). ${ }^{38}$

\section{c. Hadis Rivâyeti ve Rivâyet Ettiği Eserler}

Kerîme'nin hayatına yer veren kaynaklar, onun hem şahsî hem de ilmî kişiliğinden övgüyle bahsetmişlerdir. Talebelerinden Münzirî, hocasının asil bir kişiliğe ${ }^{39}$ sahip olduğunu, İbnü's-Sâbûnî de sâliha bir kadın ${ }^{40}$ olduğunu söylemiştir. Kerîme'nin uzun ömürlü olduğuna dikkat çeken Zehebî ise, onun hadis alanındaki şöhretini müsnidetü'ş-Şam ${ }^{41}$ ifadesiyle dile getirmiştir. Son dönem araştırmacılarından Ömer Rıza Kehhâle (v. 1408/1987) de İslâm tarihinin önemli kadın şahsiyetlerini ele aldığı A'lâmü'n-nisâ adlı eserinde Kerîme'nin fazilet sahibi bir kadın muhaddis ${ }^{42}$ olduğundan bahsetmiştir.

Kerîme, ömrünün sonuna kadar hadisle iştigal etmiş ve bu uğurda gecesini gündüzüne katmış ender kadın muhaddislerdendir. Kaynaklar, onun uzun yıllar hadis rivâyeti ve tedrisiyle meşgul olduğunu zikretmektedir. Talebesi İbnü's-Sâbûnî ilim tedrisi ile geçen bu zaman diliminin, bir süre belirtmeksizin oldukça uzun bir dönem olduğuna işaret ederken ${ }^{43}$ bir diğer talebesi

38 Zehebî, Târihu'l-İslâm, XLVII, 94; Siyer, XXIII, 93.

39 Münzirî, et-Tekmile, III, 623.

40 İbnü's-Sâbûnî, Tekmiletü İkmâli'l-ikmâl, s. 284.

41 Zehebî, Târîhu'l-İslâm, XLVII, 93; Siyer, XXIII, 92.

42 Kehhâle, A'lâmü'n-nisâ fî âlemeyi'l-Arab ve'l-İslâm, Müessesetü'r-risâle, Beyrut, 1404/1984, IV, 242.

43 İbnü's-Sâbûnî, Tekmiletü İkmâli’l-ikmâl, s. 283. 
Münzirî'nin belirttiğine göre de bu sürenin 60 yılı aştığı anlaşılmaktadır. ${ }^{44} \mathrm{Ze}$ hebî ise bu müddetin 40 küsur yıl olduğundan bahsetmiştir. ${ }^{45} 13$ Cemâziyelevvel Perşembe 641/29 Ekim 1243 tarihinde ders yaptığına dair bir semâ kaydının mevcudiyeti ${ }^{46}$ onun son anlarına kadar hadisle hemhâl olduğunu göstermektedir.

Kerîme, hadis derslerini evinde yapmakla meşhur olmuş kadın muhaddislerdendir. Dımaşk'a mücâvir Maytûr ${ }^{47}$ denilen mevkideki mütevazi ev ve bahçesini âdeta bir hadis medresesine çevirmiştir. Kadın-erkek demeden nice ilim erbabı, hadis sohbetlerine katılabilmek için çocuklarıyla birlikte âli isnada sahip bu kadın muhaddisin evinin yolunu tutmuşlardır. Nitekim Âdiliyye ve Rükniyye medreseleri ile Eşrefiyye Dârülhadisi'nde müderrislik vazifesi yürütmüş ${ }^{48}$ olan devrin çok yönlü âlimlerinden Ebû Şâme el-Makdisî, oğlu Muhammed ile birlikte Kerîme'den hadis dinlediğinden sitayişle bahsetmektedir. ${ }^{49}$ Meşhur muhaddis Münzirî de ikâmet ettiği Mısır'dan kalkıp bu eve ziyâretler gerçekleştirmiştir. Ondan hadis dinlemekle yetinmeyen Münzirî, kendisinden 595/1199 yılında icâzet aldığını da belirtmiştir. ${ }^{50}$

Kerîme'nin düzenlemiş olduğu hadis meclislerine ait çok sayıda semâ kaydı günümüze ulaşmıştır. Bu semâ kayıtlarına göre dönemin pek çok meşhur ismi onun meclislerinde hazır bulunmuştur. Yaptığı hadis derslerinin tasvirini göstermesi açısından muhtelif yıllarda okutmuş olduğu Müsnedü Abdullah b. Ömer ile Ehâdîsü Ebî Ca'fer el-Mıssîsî adlı cüzlerin semâ kayıtlarına dair birtakım bilgilere aşağıdaki tabloda yer verilmiştir. ${ }^{51}$

44 Münzirî, et-Tekmile, III, 624; Hüseynî, Sılatü't-Tekmile, I, 68.

45 Zehebî, Târîhu'l-İslâm, XLVII, 94.

46 Leder, Stefan, v. dğr., Mu'cemü's-semââti'd-Dımaşkiyye, el-Ma'hedü'l-Fransî li'd-dirâsâti'lArabiyye bi-Dımaşk, 1417/1996, s. 69.

47 Yâkût el-Hamevî, Mu'cemü'l-büldân, Dârü sâdır, Beyrut,1397/1977, V, 244; Ayrıca bk. İbn Tolûn, el-Kalâidü'l-cevheriyye fî târîhi's-Sâlihiyye (thk. Muhammed İbrahim), Ervika li'd-dirâsât ve'n-neşr, Ammân, 1434/2013, I, 300-301; Ulebî, Ekrem Hasan, Hıtatü Dımaşk, Dârü't-tıbâ', Dımaşk, 1410/1989, s. 323-324.

48 Ebû Şâme, el-Müzeyyel ale'r-Ravzateyn (thk. İbrâhîm ez-Zeybek), Dârü'l-beşâiri'l-İslâmiyye, Beyrut, 1431/201, II, 125, 168, 195; Zehebî, Târîhu'l-İslâm, XLIX, 196.

49 Ebû Şâme, el-Müzeyyel, II, 63.

50 Münzirî, et-Tekmile, III, 624.

51 Semâ kayıtları Mu'cemü's-semââti'd-Dımaşkiyye'den derlenmiştir. Bk. Leder, Stefan, v. dğr., Mu'cemü's-semââti'd-Dımaşkiyye, s. 69-70, 116-117. Ayrıca bk. Yılmaz, Muhammet, Semâ Kayıtlarında Kadın Hocalar, Giriş Basımevi, Adana, 2014, s. 28-34. 


\begin{tabular}{|c|c|c|c|}
\hline \multicolumn{4}{|c|}{ Müsnedü Abdullah b. Ömer } \\
\hline Tarih & Kâriü’l-kitâb & Kâtip & $\begin{array}{l}\text { Katılan } \\
\text { Sayısı }\end{array}$ \\
\hline 634 & $\begin{array}{l}\text { Abdurrahman b. Muham- } \\
\text { med el-Makdisî }\end{array}$ & $\begin{array}{l}\text { Abdurrahman b. Muham- } \\
\text { med el-Makdisî }\end{array}$ & 3 \\
\hline $\begin{array}{l}635 \text { (Cemâziyelev- } \\
\text { vel) }\end{array}$ & Yûsuf b. Hasan en-Nâblusî & $?$ & 4 \\
\hline 637 (Ramazan) & $\begin{array}{l}\text { Abdurrahman b. Muham- } \\
\text { med el-Makdisî }\end{array}$ & $?$ & 8 \\
\hline $\begin{array}{l}637 \quad(4 \\
\text { Cumartesi })\end{array}$ & $\begin{array}{l}\text { Yahyâ b. Ebû Mansûr es- } \\
\text { Sayrafî }\end{array}$ & Ali b. Ahmed el-Ca'ferî & 3 \\
\hline $\begin{array}{l}639 \text { (2 Rebîülâhir } \\
\text { Perşembe) }\end{array}$ & Yûsuf b. Hasan en-Nâblusî & Ali b. Ahmed el-Ca'ferî & 9 \\
\hline $\begin{array}{l}639(22 \quad \text { Zilkade } \\
\text { Cumartesi })\end{array}$ & $\begin{array}{l}\text { Abdurrahman b. Hârûn et- } \\
\text { Teğlibî }\end{array}$ & $?$ & 8 \\
\hline 640 (Recep) & $\begin{array}{l}\text { Ahmed b. Muhammed el- } \\
\text { Makdisî }\end{array}$ & $?$ & 11 \\
\hline 641 (Muharrem) & $\begin{array}{l}\text { Muhammed b. Abdurrah- } \\
\text { man el-Bağdâdî }\end{array}$ & Ali b. Ahmed el-Ca'ferî & 4 \\
\hline 641 (7 Rebîulâhir) & Ahmed b. İsmâîl en-Nemerî & Ali b. Ahmed el-Ca'ferî & 3 \\
\hline $\begin{array}{l}641 \text { (13 Cemâziye- } \\
\text { levvel Perşembe) }\end{array}$ & $\begin{array}{l}\text { Muhammed b. Abdurrah- } \\
\text { man b. el-Bağdâdî }\end{array}$ & $?$ & 3 \\
\hline \multicolumn{4}{|c|}{ Ehâdîsü Ebî Ca‘fer el-Mıssîsî } \\
\hline $\begin{array}{l}629 \text { (17 Rebîülev- } \\
\text { vel) }\end{array}$ & Ahmed b. Ebu'l-Fedâil & $\begin{array}{l}\text { Muhammed b. Yûsuf el- } \\
\text { Birzâlî }\end{array}$ & 8 \\
\hline $\begin{array}{l}630 \text { (Cemâziyelev- } \\
\text { vel) }\end{array}$ & Yûsuf b. Hasan en-Nâblusî & Yûsuf b. Hasan en-Nâblusî & 5 \\
\hline $\begin{array}{l}630 \quad(23 \text { Cemâzi- } \\
\text { yelâhir })\end{array}$ & Yûsuf b. Hasan en-Nâblusî & Yûsuf b. Hasan en-Nâblusî & 13 \\
\hline $\begin{array}{l}633 \text { (19 Cemâzi- } \\
\text { yelâhir) }\end{array}$ & $\begin{array}{l}\text { Hasan b. Abdullah el- } \\
\text { Makdisî }\end{array}$ & $\begin{array}{l}\text { Hasan b. Abdullah el- } \\
\text { Makdisî }\end{array}$ & 14 \\
\hline 637 (13 Safer) & $\begin{array}{l}\text { Ahmed b. Muhammed el- } \\
\text { Abderî }\end{array}$ & $\begin{array}{l}\text { Muhammed b. Arabşâh el- } \\
\text { Hemedânî }\end{array}$ & 5 \\
\hline $\begin{array}{l}639 \text { (2 Rebîulâhir } \\
\text { Perşembe) }\end{array}$ & Yûsuf b. Hasan en-Nâblusî & Ali b. Muhammed el-Bâlisî & 24 \\
\hline
\end{tabular}

Tablo 2: Müsnedü Abdullah b. Ömer ile Ehâdîsü Ebî Ca'fer el-Mıssîsî adlı cüzlerin okunduğu meclislerle ilgili genel bilgiler 
Kerîme'nin bu meclislerinin canlı şahitlerinden İbnü's-Sâbûnî, hocasının hadis rivâyetinde yaşamış olduğu duygu yoğunluğunu şu şekilde tasvir etmektedir: "Ondan çokça hadis dinledim ve kapsamlı bir ilim aldım. O, saliha kadınlardandı. Hadis kıraati esnasında Allah Resûlü'nün (aleyhisselâm) zikri geçtiğinde sesini yükselterek salât getirir ve ona olan özleminden dolayı gözlerinden yaşlar boşalırdı."52 Özellikle bir kadın muhaddisin hadis rivâyetindeki hâl, hareket ve tarzının günümüze aktarılmış olması emsaline nadir rastlanılabilecek bir örnektir.

Kendisinden yararlanmaya gelen hiçbir ilim talibini geri çevirmeyen Kerîme'nin hadis rivâyetindeki bir diğer özelliği de her hocada bulunması gereken gayret, sebat ve sabır gibi birtakım haslete sahip olmasıdır. Bu hususiyeti karşısında hayretini gizleyemeyen Zehebî, onun hadis tedrisinde yorulmak, usanmak nedir bilmediğini, pek sabırlı ve iştiyaklı olduğunu söylemiştir. ${ }^{53}$

\section{Sahîh-i Buhârî İcâzet ve Rivâyeti}

Hadis külliyâtı içerisinde en gözde ve mümtaz bir yere sahip olan Sahîh-i Buhârî, tarih boyunca rağbet gösterilmiş kitapların başında gelmektedir. Telifinden bu yana hem tedrisi hem de üzerinde yapılan sayısız çalışmayla büyük bir üne kavuşmuştur. İlim ehli arasında bir başucu kaynağı olan bu eserin okunmasına ayrı bir ehemmiyet verilmiştir. İslâm tarihinde çok sayıda kadının da bu eserin tedrisiyle iştigal ettiği ve bu hususta ön plana çıktığı görülmektedir. Nitekim hiç evlenmemiş kadın muhaddislerden Kerîme bnt. Ahmed el-Merveziyye (v. 463/1071), Sahîh-i Buhârî tedrisiyle tanınmıştır. İslâm coğrafyasından çok sayıda âlimin kendisinden bu eseri dinlediği isimler arasında Hatîb el-Bağdâdî (v. 463/1071) de yer almaktadır. Hatîb'in, bizzat kendi kıraatıyla ondan semâ ettiği nakledilmektedir. ${ }^{54}$ Fâtıma bnt. Muhammed elBağdâdî (v. 539/1145/), Şühde bnt. Ahmed el-İberî (v. 574/1178), Sittü'lVüzerâ bnt. Ömer ed-Dımaşkîn5 (v. 716/1316) ve daha nice kadın muhaddis de bu eseri okutmakla temâyüz etmiştir. ${ }^{56}$

52 İbnü's-Sâbûnî, Tekmiletü Ikmâli'I-Ikmâl, s. 284.

53 Zehebî, Târîhu'l-İslâm, XLVII, 94.

54 Zehebî, Siyer, XVIII, 233.

55 Sözü edilen kadın muhaddisler hakkında bk. Yılmaz, Muhammet, Kadın Hadisçiler, s. 26-28, 66-67.

56 Sahîh-i Buhârî tedrisiyle ön plana çıkmış kadınlar hakkında bk. Muhammed b. Azzûz, Safahâtün müşrakatün min inâyeti'l-mer'a bi-Sahîhi'l-Imâm el-Buhârî, Dârü İbn Hazm, Beyrut, 1423/2002. 
Zikredilen kadınlar gibi Kerîme bnt. Abdülvehhâb da Sahîh-i Buhârî okutmakla meşhur olmuştur. Ancak o, bu kitabın rivâyetine semâ değil de icâzet yoluyla sahip olmuştur. Bu icâzetini ise Horasan diyarının meşhur muhaddisi Ebü'l-Vakt Abdülevvel es-Siczî'den (v. 553/1158) almıştır. Ebü'l-Vakt da Sahîh-i Buhârî rivâyetini hocası Ebu'l-Hasan Abdurrahman b. Muhammed ed-Dâvûdî el-Bûşencî'den (v. 467/1075) semâen almıştır. Onun hocasından semâı henüz yedi yaşında hadis dinlemek için babasıyla birlikte Herat'tan Bûşenc'e yaya gidip geldiği 465/1073 yılında gerçekleşmiştir. ${ }^{57}$ Dâvudî de Türkmenistan bölgesindeki Serahs'ta hatiplik yapmış muhaddislerden Ebû Muhammed Abdullah b. Hammûye el-Hamevî'den (v. 381/991) 381/991 yılında, ${ }^{58}$ el-Hamevî ise Ebû Abdullah Muhammed b. Yûsuf el-Firebrî'den (v. 320/932) 316/929 yılında semâ etmiştir. ${ }^{59}$ Firebrî̀nin Sahîh-i Buhârî̀yi İmâm Buhârî'den iki kez dinlediği rivâyet edilmektedir. Bunlardan birincisi 248/862 yılında Firebr'de, diğeri ise 252/866 yılında Buhârâ'da gerçekleşmiştir. ${ }^{60}$

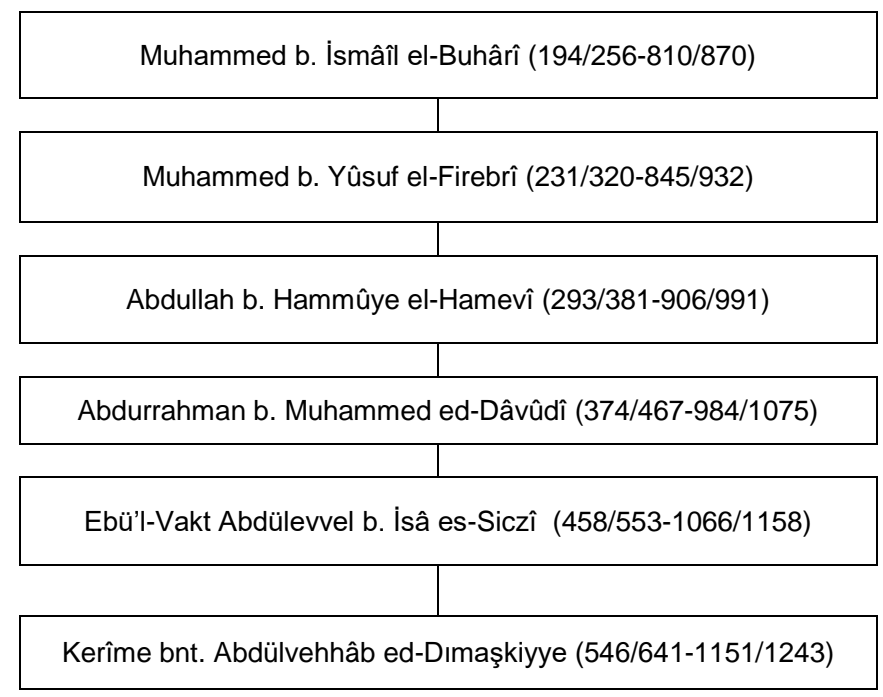

Tablo 3: Kerîme'nin Sahîh-i Buhârî icâzetinin Buhârî'ye ulaşan senedi

57 İbn Nukta, et-Takyîd, II, 698; Zehebî, Siyer, XX, 307-308; İbn Rüşeyd, Ifâdetü'n-nasîh bi'tta'rîf bi-senedi'l-Câmi'i-s-Sahîh (thk. Muhammed el-Habîb), Tunus, 1394/1974, s. 119.

58 İbn Nukta, et-Takyîd, II, 615; Zehebî, Siyer, XVIII, 223; İbn Rüşeyd, Ifâdetü'n-nasîh, s. 127; Cum‘a Fethî, Rivâyâtü'l-Câmi'i's-Sahîh ve nüsahuhu, Vezâretü’l-evkâf ve'ş-şuûni'l-İslâmiyye, Katar, 1434/2013, I, 283.

59 İbn Nukta, et-Takyîd, II, 592; Zehebî, Siyer, XVI, 493; İbn Rüşeyd, Ifâdetü’n-nasîh, s. 33; Cum'a Fethî, Rivâyâtü'l-Câmi'i's-Sahîh, I, 280.

60 İbn Nukta, et-Takyîd, I, 291; İbn Rüşeyd, Ifâdetü'n-nasîh, s. 16; Zehebî, Siyer, XV, 11; Kandemir, M. Yaşar, "el-Câmiu's-Sahîh", DiA, VII, 116, Fîrebrî'nin bu semâının üç kez gerçekleştiğine dair bir görüş için bk. Cum‘a Fethî, Rivâyâtü'l-Câmi'i's-Sahîh, I, 189-193. 
Ebu'l-Vakt es-Siczî rivâyeti âlimler arasında hüsnü kabul görmüş rivâyetlerdendir. Nitekim İmâm Nevevî, tamamlayamadığı Sahîh-i Buhârî şerhine dair yazmış olduğu Mâ temessü ileyhi hâcetü'l-kârî li-Sahîhi'l-Imâmi'lBuhârî isimli kitabında Ebu'l-Vakt rivâyetinin Şâm bölgesinde meşhur olduğuna dikkat çekmiştir. ${ }^{61}$ Sahîh-i Buhârî nüshaları üzerine büyük bir mesai harcamış muhaddislerden Ebü'l-Hüseyin Ali b. Muhammed el-Yûnînî'nin (v. 701/1302), edisyon kritiğini yaptığı Firebrî nüshasında esas aldığı dört rivâyetten biri de Ebu'l-Vakt rivâyeti olmuştur. Yûnînî, söz konusu rivâyetlerden sahih bir metin inşa etmeye çalıştığı nüshasında Ebu'l-Vakt rivâyetini "zı" (ظ) rumuzuyla göstermiştir. ${ }^{62}$

Kerîme'nin, hocasından icâzeti ne zaman ve ne şekilde aldığına dair ulaşabildiğimiz kadarıyla kaynaklarda bir bilgiye yer verilmemiştir. Ancak Ebü'l-Vakt'ın Hac niyetiyle Hicâz'a gitmek için çıktığı yolculukta 21 Şevvâl 552/26 Kasım 1157 tarihinde Bağdât'a gelip ve vefat tarihi 6 Zilkade 553/29 Kasım 1158'e kadar da burada ikamet etmiş olması ${ }^{63}$ Kerîme'nin de ondan icâzeti bu tarihlerde aldığını göstermektedir. Ebü'l-Vakt, Bağdât'ta iken Sahîh-i Buhârî ile başka eserleri rivâyet etmiştir. Nitekim Bağdâtlı tarihçi İbnü'nNeccâr (v. 643/1245) vezir Ebu'l-Muzaffer İbn Hübeyre'nin (v. 560/1165) Ebü'l-Vakt'ı sarayına davet ederek halkın da katılımıyla kendisinden Sahîh-i Buhârî̉yi dinlediğini zikretmektedir. ${ }^{64}$ Ayrıca Kerîme'nin amcası Ebu'l-Mehâsin Ömer'in, 13 Cemâziyelevvel 553/12 Haziran 1158 tarihinde Bağdât'a gelerek yerleşmesi ve burada Ebü'l-Vakt'tan hadis dinlemesinden hareketle, ${ }^{65}$ bu icâzetin amcası aracılığıyla alındığını söylemek mümkündür.

Kerîme'nin Sahîh-i Buhâri'yi birden fazla okuttuğu zikredilmekle ${ }^{66}$ birlikte ne zaman okuttuğuna dair bir kayıt söz konusu değildir. Ebû Şâme'nin, Kerîme'den Sahîh-i Buhâri’yi oğlu Muhammed'le birlikte dinlediğini belirtmiş olması ${ }^{67}$ bu hususta bir fikir vermektedir. Şöyle ki, 634/1237 yılında dünyaya

61 Nevevî, Mâ temessü ileyhi hâcetü'l-kârî li-Sahîhi'l-Imâmi'l-Buhârî (thk. Ali Hasan Ali), Beyrut, ts., s. 21-22; Cum'a Fethî, Rivâyâtü'l-Câmi'i's-Sahîh, I, 395.

62 Kandemir, M. Yaşar, "el-Câmi'u's-Sahîh” DIA, VII, 117; Kızıl, Fatma, "Yûnînî, Ali b. Muhammed" DIA, XLIII, 596. Buhârî nüshalarına dair geniş bilgi için bk. Cum'a Fethî, Rivâyâtü'l-Câmi'i's-Sahîh, Özsoy, Abdulvahap, Buhârî Nüshaları ve Nüsha Farklılıklarının Mahiyeti Üzerine, Kayseri, 2016.

63 İbn Nukta, et-Takyîd, II, 699; İbn Hallikân, Vefeyâtü'l-a'yân ve enbâü ebnâi'z-zamân, III, 227.

64 İbnü'n-Neccâr, el-Müstefâd min Zeyli Târîhi Bağdâd (thk. Muhammed Mevlûd), Müessesetü'rrisâle, Beyrut, 1406/1986, s. 278-279; Zehebî, Siyer, XX, 309-310.

65 İbnü'd- Dübeysî, Zeylü Târîhi Bağdâd, IV, 330.

66 Zehebî, Siyer, XXIII, 93.

67 Ebû Şâme, el-Müzeyyel, II, 63. 
gelen Muhammed'in 643/1245'te vefat etmesi68 ve genel kabule göre semâ yaşının da beş olması, ${ }^{69}$ söz konusu okumalardan birinin 639/1241 ile 641/1243 yılları arasında gerçekleştiği söylenebilir. Bir müddet İbnü's-Salâh'ın meclislerine katılarak ondan ders almış Ebû Abdullah Muhammed b. Hüseyin b. Rezîn el-Hamevî (v. 680/1281) de Kerîme'den Sahîh-i Buhârî̉yi semâ etmiş âlimlerdendir. ${ }^{70}$ İbn Rezîn'in Dımaşk'a 630/1230'lu yıllarda gelmiş olması, ${ }^{71}$ semâının söz konusu tarihlerde gerçekleştiğini destekler niteliktedir.

\section{Rivâyet Ettiği Diğer Kitap ve Cüzler}

Bir ömür kendini hadis rivâyetine adamış Kerîme, akdettiği ders meclislerinde Sahîh-i Buhârî dışında irili ufaklı çok sayıda kitap ve cüz de rivâyet etmiştir. Sözü edilen eserler şunlardır: ${ }^{72}$

1- el-İsrâf fî menâzili'l-eşrâf: İbn Ebü'd-Dünyâ (v. 281/894) tarafından kaleme alınmıştır. Müellif kitapta âlim, yönetici, edebiyatçı vb. kimliğiyle tanınmış zevâta dair çeşitli haberlere yer vermiştir. ${ }^{73}$

2- Müsnedü Abdullah b. Ömer: Ebû Ümeyye Muhammed b. İbrahîm et-Tarsûsî'nin (v. 273/886) tahric ettiği İbn Ömer'in rivâyetlerini içermektedir. ${ }^{74}$

3- Ehâdîsü Ebî Hâmid Ahmed b. Muhammed b. Yahyâ b. Bilâl enNîsâbûrî: Nîsâbûr muhaddislerinden Ebû Hâmid Ahmed b. Muhammed'in (v. 330/942), hocalarından semâ ettiği rivâyetleri içeren bir cüzdür. ${ }^{75}$

4- Emâlî İbn Merdûye: İsfahân muhaddislerinden Ebû Bekr Ahmed b. Musa b. Merdûye'nin (v. 410/1020) imlâ ettiği rivâyetleri içerir. ${ }^{76}$ Zehebî, onun 300 imlâ meclisi akdettiğini belirtmiştir. ${ }^{77}$

68 Ebû Şâme, el-Müzeyyel, II, 39-40.

69 İbnü’s-Salâh, Ulûmu'l-hadîs, 128-131; Suyûtî, Tedrîbu'r-râvî, I, 409-410.

70 Fâsî, Zeylü't-Takyîd, I, 202.

71 Zehebî, Târîhu'l-İslâm, L, 366.

72 Ömer Rıza Kehhâle bu eserlerin bir kısmını zikretmiştir. Bk. Kehhâle, A'lâmü’n-nisâ, IV, 242243.

73 İbn Ebü'd-Dünyâ, el-lşsâf fî menâzili'l-eşrâf, (thk. Necm Abdurrahman Halef), Riyâd, 1411/1990, s. 7; Hatiboğlu, İbrahim, “İbn Ebü'd-Dünyâ” DIA, XIX, 460.

74 Elbânî, Fihrisü mahtûtâti Dâri'l-Kütübi'z-Zâhiriyye (el-Müntehab min mahtûtâti'l-hadîs), Mektebetü'I-ma'ârif, Riyâd, 1422/2001, s. 185. Müsnedü Abdullah b. Ömer adıyla Ahmed Râtib Armûş tarafından neşredilmiştir (Beyrut, 1407/1987).

75 Elbânî, Fihris, s. 206. Hâlid b. Muhammed tarafından Mecmû' fîhi sittetü eczâe hadîsiyye içerisinde (s. 307-343) neşredilmiştir (Kahire, 1429/2008).

76 Elbânî, Fihris, s. 157. Üç meclise ait kısım Selâsetü mecâlis min emâlî Ibn Merdûye ismiyle Muhammed Ziyâürrahmân el-A'zamî tarafından neşredilmiştir (Medine, 1410/1990).

77 Zehebî, Siyer, XVII, 308. 
5- Cüz'ü Muhammed er-Râfikî: Ebu'l-Hasan Muhammed b. Ahmed er-Râfıkî’nin (v. ?) hocalarından duymuş olduğu rivâyetleri ihtivâ etmektedir. ${ }^{78}$

6- Sahîfetü Hemmâm b. Münebbih: Tabiînden Hemmâm b. Münebbih'in (v. 132/750), hocası meşhur sahâbî Ebû Hureyre'ye ait rivâyetleri topladığı sahifedir. ${ }^{79}$

7- Ehâdîsü Ebî Ca'fer el-Mıssîsî (Ehâdîsü Lüveyn): Ebû Dâvûd ve Nesâî'nin, Sünen'lerinde kendisinden hadis rivâyetinde bulunduğu âlimlerden Ebû Ca'fer Muhammed b. Süleymân el-Bağdâdî'ye ${ }^{80}$ (v. 245/859) ait bir hadis cüzüdür. ${ }^{81}$

8- Mesmû'âtü Rizkullâh et-Temîmî: Ebû Muhammed Rizkullah b. Abdülvehhâb et-Temîmî el-Bağdâdî'nin (v. 488/1095) rivâyetlerini içermektedir. ${ }^{82}$

9- Mâ ravâhü'l-ekâbir an Mâlik b. Enes: Bağdâtlı muhaddis Ebû Abdullah Muhammed b. Mahled ed-Dûrî (v. 331/943) tarafından tasnif edilmiştir. ${ }^{83}$

10- el-Fevâidü'l-müntekâtü'l-garâibü'l-hisân min hadîsi Ebî Bekr elEbherî: Bağdât'ın Mâlikî muhaddislerinden Ebû Bekr Muhammed b. Abdullah el-Ebherî'ye (v. 375/986) aittir. ${ }^{84}$

11- Min hadîsi Ebî İshâk İbn Ebî Sâbit: Ebû İshâk İbrahim b. Muhammed b. Ebû Sâbit'e (v. 338/949) ait merviyyâtı içermektedir. ${ }^{85}$

12- Emâlî Ebi'l-Abbâs Muhammed b. Ya'kûb el-Esamm: Ebu'l-Abbâs Muhammed b. Ya'kûb el-Esamm'ın (v. 346/957) rivâyetlerini intivâ etmektedir. ${ }^{86}$

13- Kitâbü'l-Câmi‘ an Abdirrezzâk es-San'ânî: Günümüze ulaşan hadis eserlerinin en eskisi olduğu söylenen Ma'mer b. Râşid'e (v. 153/770) ait

\footnotetext{
78 Elbânî, Fihris, s. 388.

79 Muhammed Hamidullah tarafından neşredilmiştir (Dımaşk, 1372/1953). Bu neşir, Talât Koçyiğit tarafından Arapça metni ile birlikte Türkçe'ye tercüme edilmiştir (Ankara, 1967).

80 Zehebî, Siyer, XI, 500-502.

81 Elbânî, Fihris, s. 516-517. Ebû Bilâl Ğanîm b. Abbâs tarafından Cüz'ün fîhi min hadîsi Lüveyn ismiyle neşredilmiştir (Riyâd, 1418/1998).

82 Elbânî, Fihris, s. 389.

83 Elbânî, Fihris, s. 378. Avvâd el-Halef tarafından neşredilmiştir (Beyrut, 1416/1996).

84 İbn Hacer, el-Mecma'u'l-müesses li'l-mu'cemi'l-müfehres (thk. Yûsuf Abdurrahman elMar'aşlî), Dârü'l-ma'rife, Beyrut, 1413/1992, II, 286-287; Elbânî, Fihris, s. 186.

85 İbn Hacer, el-Mecma'u'l-müesses, II, 426; Elbânî, Fihris, s. 22-23.

86 Elbânî, Fihris, s. 235. Nebîl Sa'düddîn Cerrâr tahkikiyle Mecmû' fîhi musennefâtü Ebi'l-Abbâs el-Esamm içerisinde (s. 191-204) neşredilmiştir (Beyrut, 1425/2004).
} 
bu kitap, talebesi Abdürrezzâk es-San'ânî (v. 211/826) tarafından elMusannef in sonuna eklenmiştir. ${ }^{87}$

14- Kitâbü'd-Du'a': Ebû Abdurrahman Muhammed b. Fudayl edDabbî'nin (v. 195/811) tasnif ettiği bir eserdir. ${ }^{88}$

15- Kitâbü's-Sıyâm: Kitâbü'd-Du'a' sahibi Muhammed b. Fudayl'a ait olan bu eserin günümüze intikal etmediği zikredilmektedir. ${ }^{89}$

16- Hadîsü Ebî Bekr en-Nîsâbûrî (el-Fevâid): Abdullah b. Muhammed b. Ziyâd en-Nîsâbûrî'ye (v. 324/936) aittir. ${ }^{90}$

17- Ğarâibü Şu'be: Ebû Abdullah İbn Mende'ye (v. 395/1005) aittir. İbn Mende, bu kitapta Basra'nın meşhur tabiîn muhaddislerinden Şu'be b. elHaccâc'a (v. 160/776) ait garîb rivâyetlere yer vermiştir. ${ }^{91}$

18- Ehâdîsü Íbn Mende: Ebû Amr Abdülvehhâb b. Muhammed b. Mende'nin (v. 475/1082), hocalarından duymuş olduğu rivâyetleri ihtivâ etmektedir. ${ }^{92}$

Kerîme'ye dair sınırlı malûmat günümüze intikal etmiş olsa da onun sadece zikredilen eserlerle iktifâ etmediği bunların haricinde daha başka kitapları da rivâyet ettiği muhakkaktır. Nitekim hocası Abdurrahîm b. Ebu'l-Vefâ el-İsfahânî, İsfahânlı hocalarını içeren bir vefeyât kaleme almış, Kerîme de bunu rivâyet etmiştir. Zehebî, Kerîme rivâyetiyle gelen bu kitabı semâ ettiğini belirtmiştir. ${ }^{93}$

\section{Vefatı}

Kerîme, ilimle mücehhez, uzun ve bereketli bir ömrün ardından 14 Cemâziyelâhir gecesi 641 yılında (29 Kasım 1243) Dımaşk'ta vefat etmiştir.

87 Kandemir, M. Yaşar, "Câmi'”, DIA, VII, 94.

88 İbn Hacer, el-Mecma'u'l-müesses, II, 372; Elbânî, Fihris, s. 440. Tek yazma nüshası ve üzerinde Kerîme'nin okuttuğuna dair semâ kaydı olan bu kitap Abdülazîz b. Süleymân tarafından neşredilmiştir (Riyâd, 1419/1999).

89 Ünal, Yavuz, "Muhammed b. Fudayl”, DiA, XXX, 530.

90 İbn Hacer, el-Mecma'u'l-müesses, II, 56-57; Elbânî, Fihris, s. 199-200.

$91 \mathrm{Bu}$ eserin büyükçe dört cüzden müteşekkil olduğu söylenmektedir. Bk. İbn Hacer, elMecma'u'l-müesses, II, 426-427.

92 Vâdîâşî, Bernâmecü'l-Vâdîâşî, (thk. Muhammed el-Habîb, Mekke, 1401/1981, s. 243; Elbânî, Fihris, s. 170-171.

93 Zehebî, Târîhu'l-İslâm, XXXIX, 251. 
Ertesi sabah evinden alınan naaşı defnedilmek üzere Kâsiyûn Dağı eteklerindeki kabristana götürülmüştür. ${ }^{94}$

\section{Sonuç}

Hicrî VI. (XII) ve VII. (XIII) asırlarda yaşayan Kerîme, hadis ilmine yaptığı hizmetlerle hadis tarihinin önemli kadın şahsiyetleri arasında yerini almıştır. Onun bu alandaki başarısı ve şöhretinin arkasında ilmin hamiliğini yüklenmiş bir ailenin desteği bulunmaktadır. Doğar doğmaz kendini ilim ortamında bulan bu kadın muhaddis, hayatı boyunca ilim meclislerinden ayrılmamış ve nice ilim erbabından ders alma fırsatı elde etmiştir. Onu pek çok akranından ayıran yönü hadis musennefâtının baş yapıtlarından Sahîh-i Buhârî gibi kıymetli bir eserin rivâyetine sahip olup bu kitabı defalarca okutmasıdır. O Sahîh-i Buhârî̀yi rivâyet etmesinin yanı sıra bu devirde tedrisine ağılık verilen çok sayıda muhtelif kitapları da okutmuştur. Derslerini ve hadis sohbetlerini yaptığı evinde ve bahçesinde nice ilim adamı yetişmiştir. Bu evin, bir hadis eğitim müessesesi gibi vazife gördüğü anlaşılmaktadır. Yaptığı derslere ait semâ kayıtlarının günümüze kadar gelmiş olması da onun hadis alanına katkısının büyüklüğünü ortaya koymaktadır.

Kerîme'nin hayatı, bir kadın muhaddisin nasıl yetiştiği, ilk eğitim ve öğreniminin ne şekilde gerçekleştiği, ilim müktesebatını elde etmede hangi aşamalardan geçtiği, ne tür kitaplar okuyup ve okuttuğuna dair değerli bilgiler sunmaktadır. Kısacası onun ilim serüveninin, kadınların hadis alanındaki faaliyetlerinin arka planını aydınlatmada ve bu çerçevedeki sis perdelerini aralamada önemli ipuçları verdiğini söylemek mümkündür.

\section{Kaynakça}

Cum'a Fethî, Rivâyâtü'l-Câmi'i's-Sahîh ve nüsahuhu, I-II, Vezâretü'l-evkâf ve'ş-şuûni'l-İslâmiyye, Katar, 1434/2013.

Ebû Şâme, Abdurrahman b. İsmâîl el-Makdisî, el-Müzeyyel ale'r-Ravzateyn (thk. İbrâhîm ez-Zeybek), I-II, Dârü'l-beşâiri'l-İslâmiyye, Beyrut, $1431 / 201$.

Elbânî, Muhammed Nâsırüddîn, Fihrisü mahtûtâti Dâri'l-Kütübi'z-Zâhiriyye (elMüntehab min mahtûtâti'l-hadîs), Mektebetü'l-ma'ârif, Riyâd, 1422/ 2001.

94 Münzirî, et-Tekmile, III, 623; Ebû Şâme, el-Müzeyyel, II, 63; İbnü’s-Sâbûnî, Tekmiletü İkmâli’İkmâl, s. 284; Hüseynî, Sılatü't-Tekmile, I, 67; Zehebî, el-iber, III, 242; Fâsî, Zeylü't-Takyîd, III, 449; İbnü'l-İmâd, Şezerâtü'z-zeheb, VII, 368; Kehhâle, A'lâmü'n-nisâ, IV, 243. 
Hamevî, Yâkût b. Abdullah el-Hamevî, Mu'cemü'l-büldân, I-V, Dârü sâdır, Beyrut,1397/1977.

Fâsî, Muhammed b. Ahmed el-Fâsî, Zeylü't-Takyîd li ma'rifeti ruvâti's-sünen ve'l-mesânîd (thk. Muhammed Sâlih), I-III, Merkezü ihyâi't-türâsi'lİslâmî, Mekke, 1418/1997.

Hatiboğlu, İbrahim, “İbn Ebü'd-Dünyâ”, DiA, XIX, 457-462.

Hüseynî, Ahmed b. Muhammed el-Hüseynî, Sılatü't-Tekmile li-Vefeyâti'nnakale (thk. Beşşâr Avvâd), I-II, Dârü'l-garbi'l-İslâmî, Beyrut, 1428/2007.

İbn Asâkir, Târîhu medîneti Dımaşk (thk. Muhibbüddîn Ebû Saîd Ömer), ILXXX, Dârü'l-fikr, Beyrut, 1415/1995.

İbn Cemâa, Muhammed b. İbrahîm, Tezkiretü's-sâmi‘ ve'l-mütekellim fî edebi'l-âlim ve'l-müteallim (thk. Muhammed Mehdî), Dârü'l-beşâiri'lİslâmiyye, Beyrut, 1433/2016.

İbn Ebü'd-Dünyâ, Abdullah b. Muhammed, el-Işrâf fî menâzili'l-eşrâf (neşr. Necm Abdurrahman Halef), Riyâd, 1411/1990.

İbn Hacer, Ahmed b. Ali el-Askalânî, Nüzhetü'l-elbâb fi'l-elkâb, (thk. Abdülazîz b. Muhammed) I-II, Mektebetü'r-Rüşd, Riyâd, 1409/1989.

-------, el-Mecma'u'l-müesses li'l-mu'cemi'l-müfehres (thk. Yûsuf Abdurrahman el-Mar'aşlî), I-IV, Dârü'l-ma'rife, Beyrut, 1413/1992.

İbn Hallikân, Ahmed b. Muhammed el-Erbilî, Vefeyâtü'l-a'yân ve enbâü ebnâi'z-zamân (thk. İhsân Abbâs), I-VIII, Dârü sâdır, Beyrut, 1398/1978.

İbn Nukta, Muhammed b. Abdülğanî, et-Takyîd li ma'rifeti ruvâti's-sünen ve'lmesânîd (Şerîf b. Sâlih), I-II, Dârü'n-nevâdir, Beyrut, 1435/2014.

İbn Rüşeyd, Mil'ül-'aybe bimâ cümi'a bi-tûli'l-ğaybe fi'l-vicheti'l-vecîhe ile'lHaremeyn Mekke ve Taybe, (thk. Muhammed el-Habîb), Tunus, 1402/1982.

-------, Ifâdetü'n-nasîh bi't-ta'rîf bi-senedi'l-Câmi'i-s-Sahîh (thk. Muhammed elHabîb), Tunus, 1394/1974

İbn Tolûn, Muhammed b. Ali ed-Dımaşkî, el-Kalâidü'l-cevheriyye fî târîhi'sSâlihiyye (thk. Muhammed İbrahim), I-II, Ammân, Ervika li'd-dirâsât ve'n-neşr, 1434/2013.

İbnü'd-Dübeysî, Muhammed b. Saîd, Zeylü Târîhi Bağdâd (thk. Beşşâr Avvâd), I-V, Dârü'l-garbi'l-İslâmî, Beyrut, 1427/2006.

İbnü'l-Esîr, Ali b. Muhammed el-Cezerî, et-Târîhu'l-bâhir fi'd-devleti'lAtâbekiyye (thk. Abdülkâdir Ahmed), Dârü'l-kütübi'l-hadîse, Kahire, 1383/1963.

İbnü'l-Buhârî, Ali b. Ahmed el-Makdisî, Meşyahatü Ibni'l-Buhârî, (thk. Avaz Itkî) I-III, Dârü âlimi'l-fevâid, Mekke, 1419/1998 
İbnü'l-İmâd, Abdülhay b. Ahmed ed-Dımaşkî, Şezerâtü'z-zeheb fî ahbâri men zeheb (thk. Abdülkâdir el-Arnaût-Mahmûd el-Arnaût), I-XI, Beyrut, $1406 / 1986$.

İbnü'n-Neccâr, Muhammed b. Mahmûd el-Bağdâdî, el-Müstefâd min Zeyli Târîhi Bağdâd (thk. Muhammed Mevlûd), Müessesetü'r-risâle, Beyrut, 1406/1986.

İbnü's-Sâbûnî, Muhammed b. Ali, Tekmiletü Ikmâli'IIkmâl fi'l-ensâb ve'l-esmâ ve'l-elkâb (thk. Mustafa Cevâd), Matbûâtü'l-mecmai'l-ilmiyyi'l-Irâkî, Irak, $1377 / 1957$.

İbnü's-Salâh, Ulûmu'l-hadîs (thk. Nûreddîn Itr), Dârü'l-fikr, Dımaşk, $1427 / 2006$.

Kâdî İyâz, İyâz b. Mûsâ el-Yahsubî, el-İlmâ' ilâ ma'rifeti usûli'r-rivâye ve takyîdi's-semâ' (thk. Ahmed Ferîd), Dârü'l-kütübi'l-ilmiyye, Beyrut, 1430/2009.

Kandemir, M. Yaşar, "Câmi", DIA, VII, 94.

------, "el-Câmi'u's-Sahîh", DIA, VII, 114-123.

Kehhâle, Ömer Rıza, A'lâmü'n-nisâ fî âlemeyi'l-Arab ve'l-Islâm Müessesetü'rrisâle, I-V, Beyrut, 1404/1984.

Kızıl, Fatma, "Yûnînî, Ali b. Muhammed" DIA, XLIII, 595-596.

Kurt, Rabia, "Münzirînnin (v. 656/1258) Hadis Aldığı Kadın Hocaları Hakkında Bir Değerlendirme (et-Tekmile Özelinde)", Kahramanmaraş Sütçü İmam Üniversitesi Illahiyat Fakültesi Dergisi, 15/29, (2017).

Leder, Stefan v.dğr., Mu'cemü's-semââti'd-Dımaşkıyye, el-Ma'hedü'l-Fransî li'd-dirâsâti'l-Arabiyye bi-Dımaşk, 1417/1996.

Makrizî, Ahmed b. Ali el-Makrizî, el-Mevâ 'iz ve'l-i'tibâr bi-zikri'l-hıtat ve'l-âsâr IIII, Mektebetü medbûlâ, Kahire, 1419/1998.

Muhammed b. Azzûz, Buyûtâtü'l-hadîs bi-Dımaşk, Dârü'l-fikr, Dımaşk $1425 / 2004$.

-------, Cühûdü'I-mer'ati'd-Dımaşkiyye fî rivâyeti'l-hadîsi'ş-şerîf, Dârü'l-fikr, Dımaşk, 1425/2004.

-------, Safahâtün müşrakatün min inâyeti'I-mer'a bi-Sahîhi'I-Imâm el-Buhârî, Dârü İbn Hazm, Beyrut, 1423/2002.

------, el-Muhaddisûne'l-Meğâribe fî Dımaşk, Dârü İbn Hazm, Beyrut, $1431 / 2010$.

Muhammed Mutî‘ el-Hâfız, A'lâmü'n-nisâi'd-Dımaşkiyyât, Dârü'l-mektebî, Dımaşk, 1434/2013.

------, Mevsû'atü'l-büyûtâti'l-ilmiyye bi-Dımaşk, Dârü'l-fikr, I-IV, Dımaşk $1435 / 2014$.

Münzirî, Abdülazîm b. Abdülkavî el-Münzirî, et-Tekmile li-Vefeyâti'n-nakale (thk. Beş̧̧âr Avvâd), I-IV, Müessesetü'r-risâle, Beyrut, 1405/1984. 
Nuaymî, Abdülkâdir b. Muhammed en-Nuaymî, ed-Dâris fî târîhi'l-medâris (thk. İbrâhim Şemsüddîn), I-II, Beyrut, Dârü'l-kütübi'l-ilmiyye, 1410/1990.

Nevevî, Yahyâ b. Şeref en-Nevevî, Mâ temessü ileyhi hâcetü'l-kârî li-Sahîhi'lImâmi'l-Buhârî (thk. Ali Hasan Ali Abdülhamîd), Beyrut, ts.

Özsoy, Abdulvahap, Buhârî Nüshaları ve Nüsha Farklılıklarının Mahiyeti Üzerine, Fenomen Yay., Kayseri, 2016.

Safedî, Halîl b. Aybeg es-Safedî, el-Vâfî bi'l-vefeyât (thk. Ahmed el-ArnaûtTürkî Mustafa), I-XXIX, Dâru ihyâi't-türâsi'l-Arabî, Beyrut, 1420/2000.

Sallâbî, Ali Muhammed, ed-Devletü'z-Zengiyye, Dârü'l-ma'rife, Beyrut, 2007.

Suyûtî, Abdurrahman b. Ebû Bekr, Tedrîbu'r-râvî fî şerhi Takrîbi'n-Nevevî (thk. Bedî‘ es-Seyyid el-Lehhâm), I-II, Dârü'l-kelimi't-tayyib, Dımaşk, 1426/ 2005.

Şeşen, Ramazan, Eyyûbîler, İsam Yay., İstanbul, 2012.

Şümeysânî, Hasan, Medârisu Dımaşk fi'l-asri'l-Eyyûbî, Dârü'l-afâki'l-cedîde, Beyrut, 1403/1983.

Ulebî, Ekrem Hasan, Hıtatü Dımaşk, Dârü’t-tıbâ‘, Dımaşk, 1410/1989.

Ünal, Yavuz, "Muhammed b. Fudayl", DiA, XXX, 530.

Vâdîâşî, Muhammed b. Câbir el-Vâdîâşî, Bernâmecü'l-Vâdîâşî (thk. Muhammed el-Habîb), Mekke, 1401/1981

Yılmaz, Harun, Zengî ve Eyyûbî Dımaşk'ında Ulema ve Medrese, Klasik Yay., İstanbul, 2017.

Yılmaz, Muhammet, Semâ Kayıtlarında Kadın Hocalar, Giriş Basımevi, Adana, 2014.

Kadın Hadisçiler, Araştırma Yayınları, Ankara, 2008.

Zehebî, Muhammed b. Ahmed ez-Zehebî, Târîhu'l-İslâm ve vefeyâtü'lmeşâhir ve'l-a'lâm (thk. Ömer Abdüsselâm Tedmürî), Dârü'l-kitâbi'lArabî, I-LIII, Beyrut, 1418/1997.

-------, Siyeru a‘lâmi'n-nübelâ, (thk. Şuayb el-Arnaût v. dğr.), I-XXIII, Müessesetü'r-risâle, Beyrut, 1401-1405/1981-85.

-------, el-Iber fî haberi men gaber (thk. M. Saîd Zağlûl), I-V, Dârü'l-kütübi'lilmiyye, Beyrut, 1405/1985.

-------, Tezkiretü'l-huffâz (thk. Zekeriyyâ Umeyrât), I-V, Dârü'l-kütübi'l-ilmiyye, Beyrut, 1419/1998

------, el-Emsâr zevâtü'l-âsâr (thk. Mahmûd el-Arnaût), Dârü İbn Kesîr, Dımaşk, 1405/1985. 


\section{The Woman Muhaddith Has a ljazah of al-Sahih al-Bukhari: Karimah bnt. Abdulvehhâb}

Citation / (C)- Kurt, A. (2018). The Woman Muhaddith Has a ljazah of al-Sahih al-Bukhari: Karimah bnt. Abdulvehhâb, Çukurova University Journal of Faculty of Divinity, 18 (1), 453-476.

Abstract- The period of the second half of the sixth century and the first half of the seventh century and surroundings that Kerime living on had witnessed with two important occurrance, such as Crusader and Mongol attacks that closely related the world and Islamic history with cause and effects. However, despite the great losses and destructions caused by these events, it was observed that the scientific activities continued at a rapid pace in this period and the great increase in the facilities of education and training institutions such as madrasah, dar alhadiths, hanqah was occurred. Kerime, born and grow up in the city of Damascus, was a member of a well-respected and wellknown family that came to the fore with hadith scholars they raised. This situation paved the way for her to meet science at an early age. Both her personal effort and her training in a family that come from the wisdom class led her to fame in a short time about hadith. This woman who was one of the rare figure that marked an era recieved having ali-isnad thanks to her long life. For this reason, she had opportunity to meet with many hodja and hear hadiths from them and also actively participated in the training of many students. The important figures of the hadiths have kept the way to the her house with great enthusiasm to join her councils. The most important characteristic of Kerime, who devoted his life to the narration of hadiths, was that she has repeatedly read el-Cami'us-Sahih which belongs to Imam Bukhari with ijazet that she recieved from Abu al-Vaqt al-Sijzi who had been the famous muhaddith of the Khorasan region and other works which she had the permission of the narration. This study that has been subject to Kerime's life and her contribution to hadith, aims to reveal the existence and effectiveness of women muhaddith in history through her.

Keywords- Karimah bnt. Abdulvehhâb, ljazet, narration, woman muhaddith, al-Sahih al-Bukhari 